\title{
EVALUASI PERANCANGAN ANGGARAN BIAYA DAN WAKTU MENGGUNAKAN METODE BIM
}

\author{
Puteri Khodijatuz Zahro $^{1)}$, Anik Ratnaningsih'), Akhmad Hasanuddin ${ }^{3)}$ \\ ${ }^{1,2), 3)}$ Jurusan Teknik Sipil Universitas Jember \\ Email: puterikhodijatuz27@gmail.com ${ }^{1)}$, anik.teknik@unej.ac.id ${ }^{2)}$, \\ ahmadhasanuddin11@ gmail.com ${ }^{3)}$
}

DOI: http://dx.doi.org/10.29103/tj.v11i2.529

(Received: May 2021 / Revised: August 2021 / Accepted: September 2021)

\begin{abstract}
Abstrak
Universitas Jember yang sedang dalam masa pembangunan yang menyebabkan dibutuhkannya teknologi pendukung untuk proses yang dilakukan agar didapatkan hasil yang efisien sehingga dibutuhkan kinerja manajemen proyek yang memfasilitasi proses desain dan konstruksi yang lebih terintegrasi yaitu Building Information Modeling (BIM). Sebelumnya dikenal beberapa program bantu seperti AutoCAD, SAP, SketchUp 3D, Ms. Project dan program bantu lainnya yang penggunaannya hanya sebatas dalam satu jangkauan. Penggunaan BIM yang mengintegrasi gambar proyek, volume pekerjaan dan estimasi harga dapat mempermudah proses pengerjaan menjadi lebih singkat dan cepat. Oleh karena itu, pada penelitian ini dilakukan evaluasi antara penggunaan metode BIM dan metode konvensional pada Proyek Pembangunan Gedung Kuliah Fakultas Keperawatan Universitas Jember. Program bantu BIM yang dipakai adalah Autodesk Revit yang merupakan salah satu perangkat lunak yang membawa semua arsitektur, teknik, dan disiplin konstruksi ke dalam lingkungan pemodelan terpadu. Hasil dari Penelitian ini yaitu menghasilkan selisih biaya total untuk struktur dan arsitektur yaitu Rp242.638.340,10. Biaya yang berasal dari pemodelan Autodesk Revit lebih besar 5,33 \% daripada metode konvensional proyek. Dan selisih pada penjadwalan dalam pelaksanaan pada pemodelan Autodesk Revit yaitu 15 hari lebih lama daripada metode konvensional.
\end{abstract}

Kata Kunci: BIM, Autodesk Revit, Rencana Anggaran Biaya, Penjadwalan Proyek

\begin{abstract}
Universitas Jember, during this construction period, requires supporting technology for the process to obtain efficient results so it takes a project management performance that facilitates a more integrated design and construction process, namely Building Information Modeling (BIM). Previously known several auxiliary programs such as AutoCAD, SAP, SketchUp 3D, Ms. Projects and other assistance programs restricted to a single scope. The use of BIM that integrates project designs, workload and price estimates can make the process shorter and faster. Therefore, in this study a comparison was made between the use of the BIM method and the conventional method in the Lecture Building Project for the Faculty of Nursing, Universitas Jember. The BIM assistant program used is Autodesk Revit which is a software that brings all architecture, engineering, and construction disciplines into a unified modeling environment. The results of this study showed a total cost difference in structure and architecture of IDR $242,638,340.10$. On the other hand, the Autodesk Revit modeling cost was greater than the conventional method with a percentage of $5.33 \%$. Furthermore, the difference in the Autodesk Revit modeling implementation schedule is 15 days longer than the conventional method.
\end{abstract}

Keywords: BIM, Autodesk Revit, Budget-Estimate Plan, Project Scheduling

Evaluasi Perancangan Anggaran Biaya Dan Waktu Menggunakan Metode BIM - 


\section{Latar Belakang}

Universitas Jember akan membangun satu gedung yang akan difungsikan sebagai gedung kuliah pada Fakultas Keperawatan, agar didapatkan hasil yang efisien maka dibutuhkan kinerja manajemen proyek yang memfasilitasi proses desain dan konstruksi yang lebih terintegrasi yaitu Building Information Modeling (BIM). Konsep BIM membayangkan konstruksi virtual sebelum konstruksi fisik yang sebenarnya untuk mengurangi ketidakpastian, meningkatkan keselamatan, menyelesaikan masalah, dan menganalisis dampak potensial (Smith. D, 2007). BIM berimplikasi memberi perubahan, mendorong pertukaran model 3D antara disiplin ilmu yang berbeda, sehingga proses pertukaran informasi menjadi lebih cepat dan berpengaruh terhadap pelaksanaan konstruksi. (Eastman et al., 2008). Jati U. et al., (2019) mengatakan manfaat implementasi BIM seperti deteksi tabrakan desain, simulasi proyek yang jelas, pengurangan pengerjaan ulang, dan penggunaan sumber daya yang efisien.

Dalam Proyek Pembangunan Gedung Kuliah Fakultas Keperawatan Universitas Jember ini direncanakan dibangun dengan 5 lantai yang memiliki fungsi sebagai gedung kuliah. Pada penelitian ini akan dilakukan perhitungan volume pekerjaan dan penjadwalan menggunakan metode BIM dengan program bantu Autodesk Revit dan Microsoft Project guna mendapatkan hasil perencanaan konstruksi yang lebih efisien dan efektif.

Peneliti terdahulu yaitu Farras Faridah Putri, (2019) menyimpulkan bahwa biaya yang berasal dari Revit Architecture lebih besar $1.47 \%$ dari biaya dengan metode konvensional. Peneliti lainnya Berlian P. et al., (2016) menyimpulkan bahwa penggunaan metode aplikasi BIM dapat mempercepat perencanaan proyek sebesar $\pm 50 \%$, mengurangi kebutuhan SDM sebesar 26,66\% dan menghemat pengeluaran biaya personil sebesar 52,25\% dibandingkan dengan menggunakan metode konvensional. Penelitian sebelumnya dengan bahasan yang sama dalam perbandingan BIM dan konvensional Akhmad A. K. et al., (2019) menyimpulkan hasil biaya untuk BIM lebih hemat sebesar $40,35 \%$, mutu yang lebih efektif dan efisien dalam pengontrolannya, dan mempercepat waktu sebesar 46,15 dibandingkan menggunakan metode konvensional, sementara Rizaldi et al., (2017) menyimpulkan hasil yang diperoleh dari perhitungan $\mathrm{RAB}$ dengan menggunakan aplikasi BIM sekitar 10\% lebih rendah jika dibandingkan dengan perhitungan secara manual/konvensional.

Tujuan penelitian ini adalah untuk mengevaluasi penggunaan BIM terhadap anggaran biaya dan waktu dengan membandingkan pada metode konvensional yang telah direncanakan sebelumnya oleh pihak proyek.

\section{Metode Penelitian}

Penelitian ini menggunakan metode BIM dengan program bantu Autodesk Revit dan menghasilkan gambar 2D, gambar 3D, perhitungan volume dan perhitungan biaya pada setiap item pekerjaan, serta program bantu Microsoft Project untuk mendapatkan jumlah durasi pekerjaan.

\subsection{Studi Literatur}

Melakukan studi literatur terhadap materi Building Information Modelling (BIM) yang dilakukan dengan mencari referensi jurnal, skripsi atau penelitian terdahulu, buku dan artikel yang berkaitan. 


\subsection{Identifikasi Masalah}

Pada tahap ini dilakukan analisa proyek Gedung Kuliah Fakultas Keperawatan Universitas Jember untuk dimodelkan ke dalam pemodelan BIM dengan menggunakan program bantu perangkat lunak Autodesk Revit.

\subsection{Pengumpulan Data}

Data yang digunakan pada penelitian ini merupakan data sekunder yang diperoleh langsung dari kontraktor. Data-data yang digunakan dalam penelitian ini terdiri dari:

1. Data Detailed Engineering Design (DED) yang digunakan untuk import file pada aplikasi BIM dan memulai pengerjaan pada aplikasi BIM;

2. Analisa Harga Satuan Pekerjaan (AHSP) sebagai perhitungan RAB dan durasi pekerjaan;

3. Bill of Quantity (BoQ) dan Rencana Anggaran Biaya (RAB) tiap volume pekerjaan proyek untuk bahan evaluasi perbandingan anggaran biaya pada metode konvensional.

\subsection{Pemodelan}

Pemodelan adalah tahapan (langkah) dalam membuat model dari suatu sistem nyata (realitas) (Sridadi, 2009). Salah satu hal yang perlu dilakukan sebelum melakukan langkah-langkah pemodelan gedung menggunakan program bantu Autodesk Revit dan Microsoft Project adalah mempelajari pedoman dari shop drawing proyek. Berikut ini akan dijelaskan langkah-langkah pemodelan Gedung Kuliah Fakultas Keperawatan Universitas Jember menggunakan Autodesk Revit.

1. Login Program dan Membuat File Project Baru

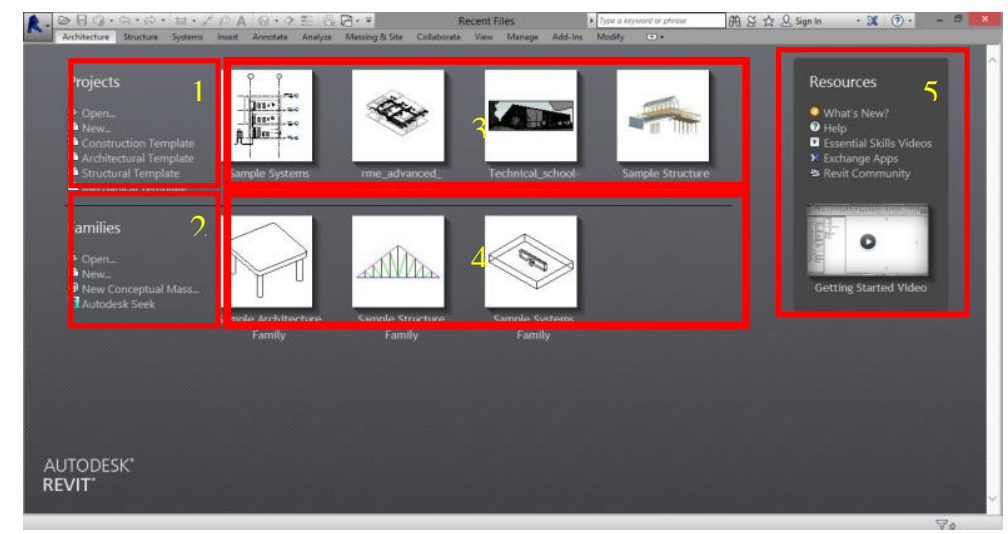

Gambar 1 Tampilan awal Autodesk Revit

Langkah awal yang dilakukan adalah membuka program Autodesk Revit yang sudah di install di perangkat, akan muncul tampilan awal seperti Gambar 4.

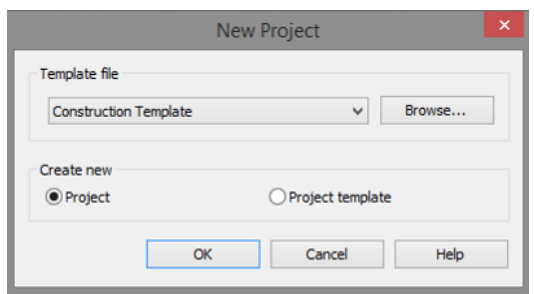

Gambar 2 Kotak dialog New Project

Evaluasi Perancangan Anggaran Biaya Dan Waktu Menggunakan Metode BIM -

Puteri Khodijatuz Zahro, Anik Ratnaningsih, Akhmad Hasanuddin 
Dalam penelitian ini akan dibuat file project baru, sehingga digunakan menu pilihan "New". Setelah itu akan muncul kotak dialog new project seperti Gambar 5, yang dilakukan adalah memilih Construction Template pada Template file dan memilih Project dalam pilihan Create new, lalu tekan OK.

2. Interface Autodesk Revit dan Mengatur Unit Satuan

Setelah masuk memilih jenis project yang akan digunakan seperti pada Gambar 2, maka akan muncul Tampilan Antarmuka (Interface) Autodesk Revit seperti Gambar 3.

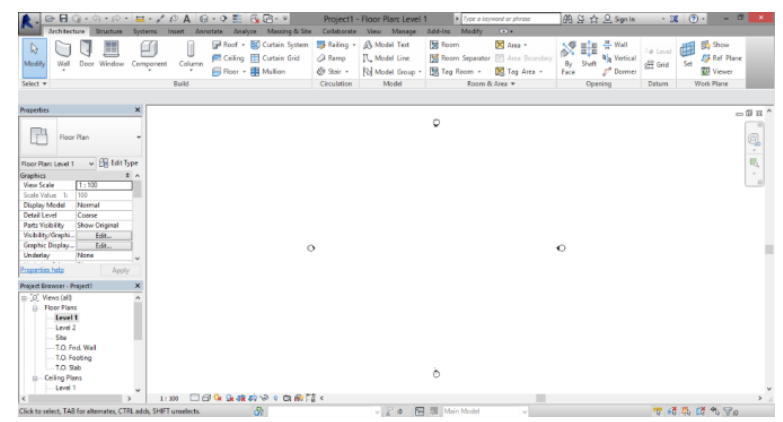

Gambar 3 Tampilan antarmuka (Interface) Autodesk Revit

Konfigurasi unit dengan mengatur satuan yang merupakan hal dasar yang dilakukan setiap akan membuat project baru. Kotak dialog Project Unit dapat ditampilkan dengan cara tekan tab Manage $\rightarrow$ panel Settings $\rightarrow$ Project Units atau dapat menggunakan command "UN". Dalam pemodelan ini, satuan dan format yang digunakan dapat dilihat dalam gambar 4 .

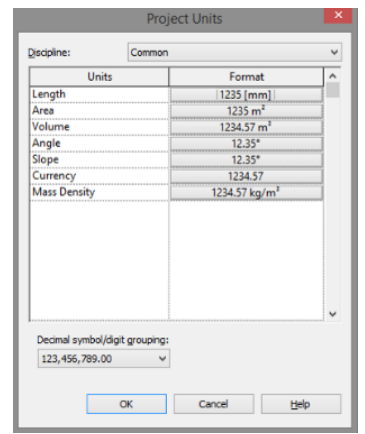

(a)

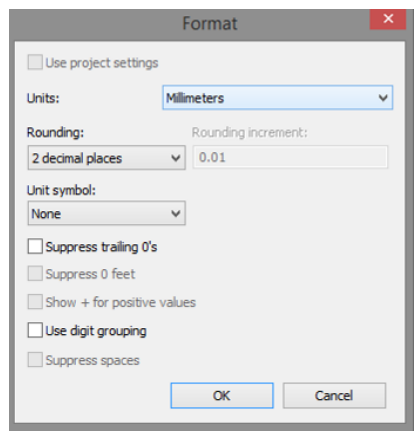

(b)

(a) Kotak Dialog Project Units; (b) Kotak Dialog Format Units-Length Gambar 4 Setting project units

3. Import File CAD (.dwg) ke Autodesk Revit

Autodesk Revit merupakan perangkat lunak yang memiliki kemampuan mendukung beberapa format file untuk proses import dan export, salah satunya yaitu file dengan ekstensi .dwg yang dapat dilakukan dengan cara tekan tab Insert $\rightarrow$ panel Import $\rightarrow$ Import CAD atau Link CAD. Link CAD memiliki fungsi mempertahankan referensi pada file CAD yang ditautkan dan akan langsung diperbarui ketika model dari Autodesk Revit dibuka kembali atau file yang ditautkan dimuat ulang. Sedangkan, Import CAD memiliki fungsi menghilangkan koneksi ke sumbernya dari file yang diimpor menjadi bagian dari model Autodesk Revit. 


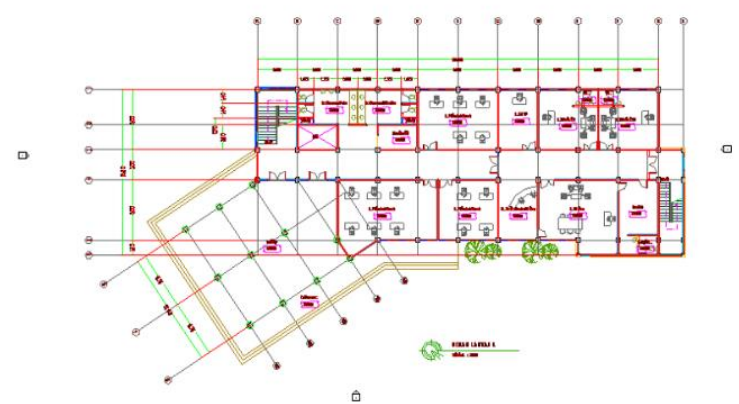

Gambar 5 Import file CAD ke Autodesk Revit

Jika Gambar hasil import file CAD ke Autodesk Revit berada di pinggir drawing area, maka dapat dipindah ke dalam drawing area dengan cara tekan Modify $\rightarrow$ Unpin $\rightarrow$ Move.

4. Gridlines

Grid Lines merupakan salah satu tools datum dalam Autodesk Revit yang dipakai sebagai garis referensi atau guidelines dalam pembuatan model. Dalam menambahkan grid, level floor plans view yang ditampilkan adalah pada saat Level 1. Grid dapat dibuat dengan tekan tab Architectural $\rightarrow$ panel Datum $\rightarrow$ Grid.

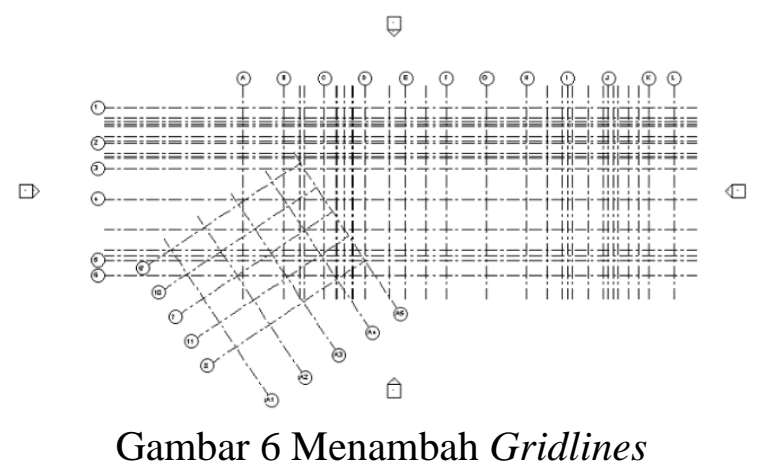

5. Level

Level merupakan salah satu tools dalam panel Datum Autodesk Revit yang memiliki fungsi sebagai parameter pijakan untuk menempatkan elemen bangunan secara vertikal. Tools Level ini memudahkan dalam mengelompokkan elemen bangunan yang harus dipasang pada ketinggian yang sama atau berbeda. Sebelum membuat Level, terlebih dahulu tekan Elevation (Building Elevation) yang terdapat di kiri drawing area pada Project Browser $\rightarrow$ East, North, South atau West.

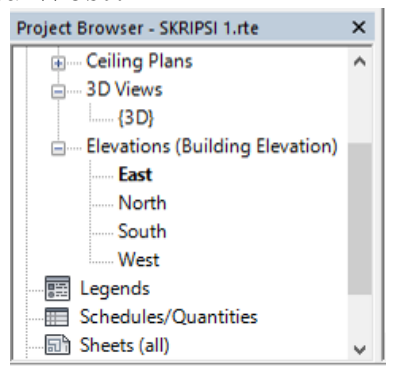

Gambar 7 User Interface Project Browser 
View merupakan tampilan pada model dari perspektif ketinggian elevasi dari empat arah sesuai default template atau arah lain yang ditentukan. View memiliki istilah lain yaitu tampak kanan, tampak kiri, tampak depan dan tampak belakang. Level dapat dibuat dengan tekan tab Architectural $\rightarrow$ panel Datum $\rightarrow$ Level. Elevasi per lantai yang digunakan dalam proyek konstruksi Gedung Kuliah Fakultas Keperawatan Universitas Jember adalah 4000 mm.

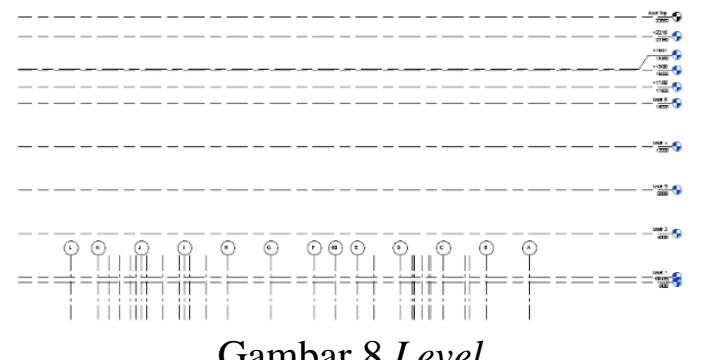

Gambar 8 Level

Setelah menambah level sesuai kebutuhan, grid yang sudah dibuat menjadi pendek seperti pada gambar 8. Maka yang perlu dilakukan adalah dengan memperpanjang grid dengan cara tekan salah satu gridline, lalu menekan menekan ujung gridline yang bertanda lingkaran tanpa dilepas, kemudian tarik untuk memperpanjang gridline tersebut. Gridline lain akan ikut memanjang mengikuti salah satu gridline sehingga tidak perlu untuk mengedit semua gridline.

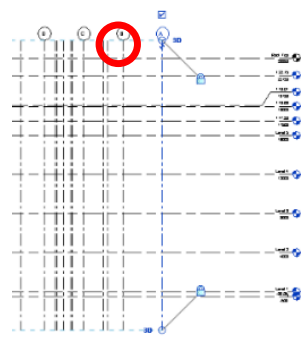

(a) Tampilan Lingkaran dalam gridlines; (b) Tampilan Gridlines setelah ditarik
Gambar 9 Mengubah panjang gridlines

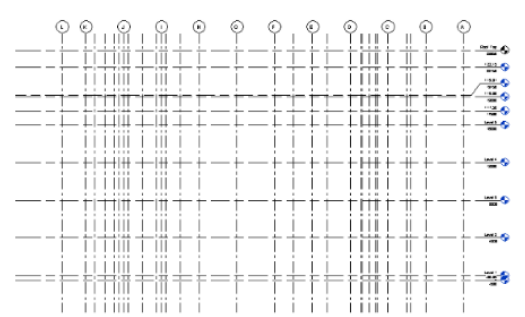

(a) Tampilan LingKaran dalam gridlines; (b) Tampilan Gridlines setelah ditarik
Gambar 9 Mengubah panjang gridlines

\subsection{Pemodelan Struktur}

Pemodelan struktur yang dibutuhkan terdiri dari pemodelan pondasi, sloof, kolom, balok, pelat dan tulangan-tulangannya. Salah satu contoh pemodelan dalam struktur yaitu struktur kolom dilakukan dengan menggunakan lima tipe kolom berdasarkan dimensi tiap parameter. Langkah pertama yang dilakukan dalam pemodelan struktur kolom adalah dengan menggunakan tools Structural Column pada tab Structure $\rightarrow$ panel Structure $\rightarrow$ Column atau menggunakan command "CL". Lalu dalam tab Modify/Place Structural Column pilih Height untuk kolom yang menerus ke atas dan pilih batas level untuk batas atas kolom yang akan dimodelkan. Setelah itu tekan Edit Type pada Properties untuk mengubah dimensi sesuai yang direncanakan. Ubah bentuk dan tipe kolom dengan memilih Load dan atur dimensi kolom sesuai parameter serta beri nama untuk masing-masing tipe kolom yang dibuat sesuai perencanaan. 


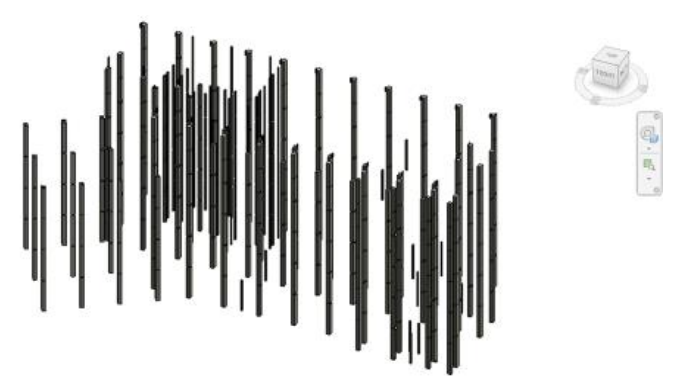

Gambar 10 Hasil pemodelan struktur kolom

\subsection{Pemodelan Arsitektur}

Pemodelan arsitektur terdiri dari pemodelan dinding, pintu, jendela, tangga, plafond dan atap. Contoh pemodelan dalam arsitektur dinding yang menggunakan view Floor Plan dan jenis dinding yang digunakan merupakan dinding pembatas ruang dengan tebal $15 \mathrm{~cm}$.

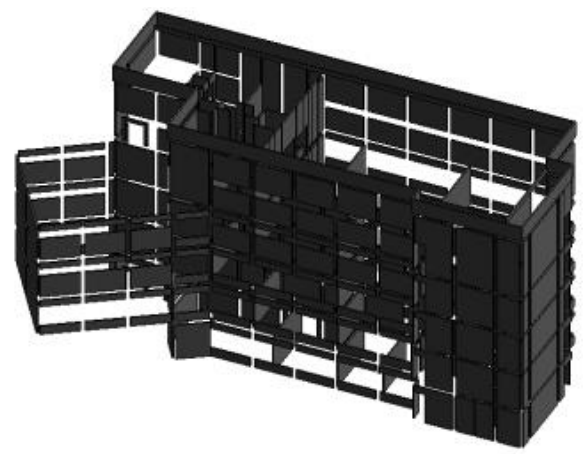

Gambar 11 Hasil pemodelan arsitektur dinding

Langkah awal yang dilakukan dalam memodelkan dinding yaitu dengan memilih tools Wall dengan menekan tab Architecture $\rightarrow$ panel Build $\rightarrow$ Wall atau menggunakan command "WA". Lalu untuk mengubah parameter yang diinginkan sesuai perencanaan yaitu dengan menekan Edit Type yang berada pada user interface Properties sehingga kotak dialog Type Properties akan muncul. Parameter Width dalam kotak dialog Type Properties dapat disesuaikan dengan menekan Edit pada Value dari parameter Structure sehingga kotak dialog Edit Assembly akan muncul. Setelah dilakukan pengaturan parameter, maka dinding dapat dimodelkan satu-satu atau dapat menggunakan tools Copy atau dengan menggunakan command "CO".

\subsection{Schedules/Quantities}

Menu Schedules/Quantities dalam Autodesk Revit merupakan menu yang berfungsi sebagai list atau susunan informasi dari hasil pemodelan dalam bentuk tabel. Menu ini dapat mencantumkan setiap contoh jenis family, material, harga, dan lain-lain sesuai pemodelan serta dapat diciutkan kedalam kelompok berdasarkan kriteria yang diinginkan.

Untuk membuat Menu Schedules/Quantities dapat menggunakan tools yang terdapat pada tab View $\rightarrow$ panel Creat $\rightarrow$ Schedules. Dalam kotak dialog New Schedule dapat memilih jenis susunan informasi yang akan dibuat dan tekan OK. Lalu akan muncul kotak dialog Schedule Properties dan dalam kotak dialog tersebut dapat disusun jenis informasi yang akan dibuat dengan cara memindah jenis informasi ke kolom sebelah kanan. 


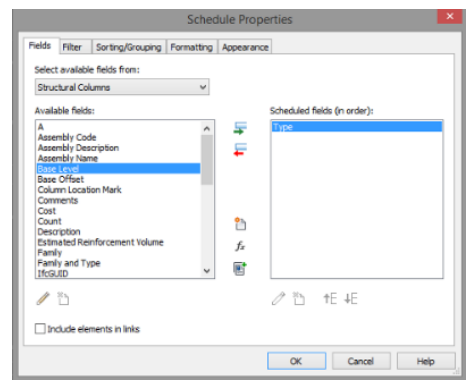

Gambar 12 Kotak dialog Schedule Properties

Setelah membuat jenis informasi yang akan dibuat pada kotak dialog Schedule Properties, maka akan langsung muncul Schedules/Quantities.

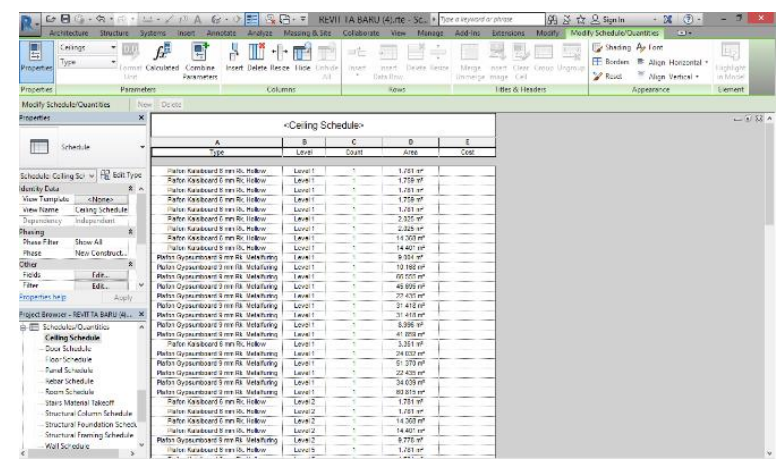

Gambar 13 Hasil Schedules/Quantities Plafon Autodesk Revit

\subsection{Rencana Anggaran Biaya (RAB)}

Rencana Anggaran Biaya (RAB) didapat dengan adanya data DED, RKS, AHS dan Volume dari pemodelan Autodesk Revit. RAB pada struktur dan arsitektur yang sudah dimodelkan dapat diketahui dalam menu Schedules/ Quantities yang telah dibuat sebelumnya. RAB dapat diketahui dengan menambah harga tiap material dalam $1 \mathrm{~kg}, 1 \mathrm{~m}^{2}$ dan $1 \mathrm{~m}^{3}$ dengan memasukkan harga pada cost yang terdapat dalam menu Type Properties pada Autodesk Revit. Untuk menghitung $\mathrm{RAB}$ digunakan rumus:

$$
R A B=\text { Volume } x \text { Harga Satuan }
$$

Hasil RAB yang didapatkan menggunakan metode BIM program bantu Autodesk Revit berjumlah $\mathrm{Rp}$ 4.764.801.345,05 dan metode konvesional berjumlah $\mathrm{Rp}$ 4.550.618.576,31 dengan selisih Rp 214.182.768,74.

\subsection{Penjadwalan}

Menurut Muhtadi (2009), penjadwalan adalah proses mengurutkan tugas/ jenis-jenis pekerjaan dalam rangkaian aktivitas yang akan dilaksanakan. Penjadwalan proyek Gedung Kuliah Fakultas Keperawatan Universitas Jember akan dibuat dengan perencanaan WBS (rincian item pekerjaan yang akan dibuat untuk menghasilkan durasi tiap pekerjaan), AHSP (hitungan per satuan pekerjaan konstruksi yaitu kebutuhan bahan bangunan dan harga bahan bangunan, upah kerja dan standar pengupahan pekerja serta kebutuhan peralatan dan harga sewa/beli peralatan yang dibutuhkan), produktivitas tenaga kerja dan alat, serta durasi pekerjaan. 
a. WBS (Work Breakdown Structure) merupakan salah satu hal yang perlu diperhatikan dalam membuat penjadwalan karena WBS berguna dalam merincikan item pekerjaan yang akan dibuat untuk menghasilkan durasi tiap pekerjaan khususnya pada struktur dan arsitektur proyek konstruksi gedung.

Tabel 1 Work Breakdown Structure

\begin{tabular}{clcc}
\hline No & \multicolumn{1}{c}{ URAIAN PEKERJAAN } & VOLUME & Ls \\
\hline A & PEKERJAAN PONDASI & & \\
\hline 1 & Pekerjaan Mobilisasi dan Demobilisasi Peralatan Bor & 1,00 & Ls \\
\hline 2 & Pekerjaan Pengeboran Tanah Strous D40 & 232,00 & Titik \\
\hline 3 & Pekerjaan Supply Beton & 0,00 & 0,00 \\
\hline 4 & Pekerjaan Penulangan & 0,00 & 0,00 \\
\hline 5 & PDA Test & 3,00 & Titik \\
\hline B & PEKERJAAN LANTAI 1 & & \\
\hline 1 & Pekerjaan Sloof & 6644,06 & $\mathrm{Kg}$ \\
\hline & Pekerjaan Penulangan & 559,19 & $\mathrm{~m}^{2}$ \\
\hline & Pekerjaan Bekisting & 56,55 & $\mathrm{~m}^{3}$ \\
\hline & Pekerjaan Beton K250 & & \\
\hline
\end{tabular}

b. AHSP (Analisa Harga Satuan Pekerjaan)

AHSP yang digunakan dalam perhitungan merupakan AHSP yang digunakan pula dalam perhitungan manual proyek yaitu menggunakan AHSP Universitas Jember tahun anggaran 2019.

c. Perhitungan Produktivitas Tenaga Kerja

Perhitungan produktivitas tenaga kerja menggunakan 2 rumus yaitu produktivitas pekerja dan produktivitas alat

$$
\begin{aligned}
& \text { Produktivitas Pekerja }=\frac{1}{\text { Koefisien pekerja }} \\
& \text { Produktivitas alat }=q \times N \times E
\end{aligned}
$$

\section{d. Perhitungan Durasi Pekerjaan}

Perhitungan durasi pekerjaan merupakan salah satu hal penting dalam penjadwalan yang perlu diperhitungkan dengan tepat. Durasi pekerjaan dapat diketahui dengan menggunakan data volume pekerjaan, produktivitas tenaga kerja dan jumlah tenaga kerja yang telah direncanakan.

$$
\text { Durasi }=\frac{\text { Volume Pekerjaan }}{\text { Produktivitas } \times \text { Jumlah Tenaga Kerja }}
$$

Penjadwalan proyek direncanakan dengan program bantu Microsoft Project. Menurut Trihendradi (2008), Ms. Project menduduki peringkat pertama sebagai alat bantu pendukung manajemen proyek karena mengimplikasikan keandalan software aplikasi tersebut. Penjadwalan Ms. Project dilakukan dengan memasukkan item pekerjaan, durasi dan predecessor sesuai hubungan ketergantungan setiap pekerjaan pada setiap kolom di program bantu Microsoft Project.

WBS atau item pekerjaan dapat dimasukkan dalam kolom Task Name, Durasi yang telah diperhitungkan kemudian dimasukkan dalam kolom Duration, kolom Start dapat diisikan dengan tanggal dimulainya pekerjaan dan kolom Finish dapat terisi langsung sesuai durasi yang dimasukkan sebelumnya. 
Resource Names dapat diisikan dengan memasukkan jenis sumber daya terlebih dahulu pada Resource Sheet yang dapat dimunculkan dengan menekan tab View $\rightarrow$ panel Resources view $\rightarrow$ Resource Sheet.

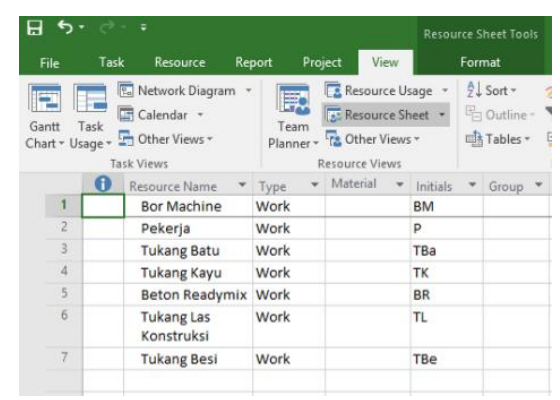

\section{Gambar 14 Resource Sheet}

Setelah menambah jenis sumber daya, maka sumber daya dapat dimasukkan langsung dalam view Gantt Chart dengan memilih jenis sumber daya yang digunakan pada kolom Resource Names dan jumlahnya dengan cara menekan baris item pekerjaan yang akan ditambahkan, lalu menekan tab View $\rightarrow$ panel Split view $\rightarrow$ Details. Kemudian dipastikan Task Type yang digunakan adalah Fixed Duration pada view details sehingga durasi dan kalender yang dimasukkan sebelumnya tidak berubah dan input jumlah sumber daya yang digunakan sesuai perencanaan pada perhitungan durasi.

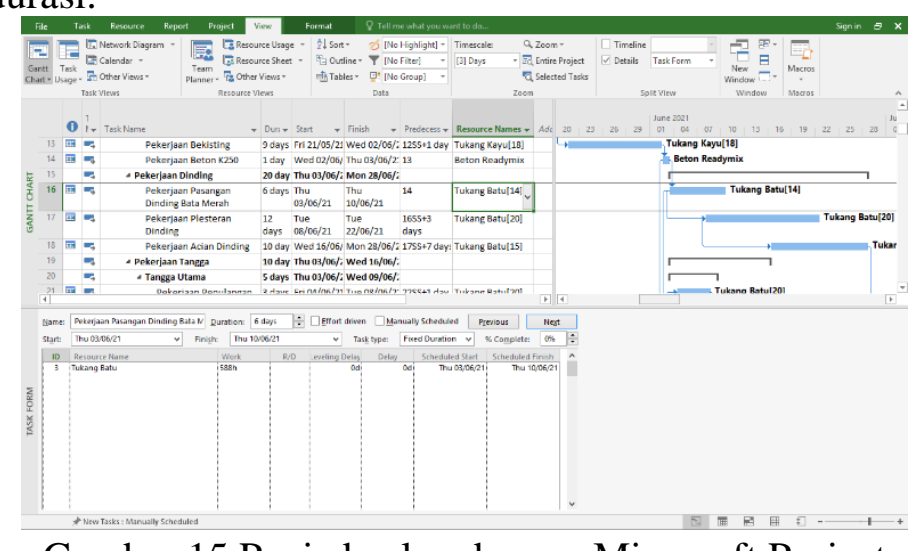

Gambar 15 Penjadwalan dengan Microsoft Project

Setelah memasukkan item pekerjaan, durasi dan predecessor dalam program banttu Microsoft Project, maka durasi pekerjaan dapat diketahui. Berikut rekap durasi pekerjaan tiap lantai:

Tabel 2 Hasil Durasi Pengerjaan

\begin{tabular}{ccc}
\hline Uraian Pekerjaan & Durasi Autodesk Revit & Durasi Konvensional \\
\hline Pekerjaan Pondasi & 35 hari & 35 hari \\
Pekerjaan Lantai 1 & 77 hari & 78 hari \\
Pekerjaan Lantai 2 & 73 hari & 73 hari \\
Pekerjaan Lantai 3 & 72 hari & 72 hari \\
Pekerjaan Lantai 4 & 71 hari & 71 hari \\
Pekerjaan Lantai 5 & 65 hari & 56 hari \\
Pekerjaan Lantai Atap & 45 hari & 41 hari \\
\hline Total Durasi & 255 hari & 240 hari \\
\hline
\end{tabular}




\section{Hasil dan Pembahasan}

Rencana Anggaran Biaya (RAB) yang didapatkan dari pemodelan Autodesk Revit seharga $\mathrm{Rp}$ 4.793.256.916,42 dan dari data sekunder proyek diperoleh harga Rp 4.550.618.576,31 dengan selisih biaya yaitu Rp 242.638.340,10 atau 4,71\%.

Perbandingan biaya yang didapat sebesar $4,71 \%$ lebih besar pada penggunaan metode BIM program bantu Autodesk Revit bertentangan dengan peneliti terdahulu Akhmad A. K. et al. (2019) yang menyimpulkan hasil biaya untuk BIM lebih hemat sebesar 40,35\% dan juga Rizaldi et al., (2017) dengan kesimpulan hasil yang diperoleh dari perhitungan RAB dengan menggunakan aplikasi BIM sekitar 10\% lebih rendah jika dibandingkan dengan perhitungan secara manual/konvensional.

Selisih waktu dalam penjadwalan menggunakan program bantu Microsoft Project yaitu 15 hari. Selisih waktu didapatkan dari pekerjaan lantai 1, pekerjaan lantai 5 dan pekerjaan atap. Selisih pada pekerjaan lantai 1 diakibatkan selisih volume dari dinding dikarenakan jendela tipe J3 dan J4 yang memiliki panjang menerus hingga lantai 5 dianggap ada pada lantai 1, sehingga pengurangan kusen pada dinding lantai 1 menjadi besar dan mengakibatkan volume dinding menjadi lebih sedikit. Selisih pada lantai 5 diakibatkan karena volume pelat dan balok yang memiliki durasi 0 hari karena human error sehingga durasi pekerjaan lantai 5 oleh metode konvensional proyek lebih kecil dari hasil program bantu Autodesk Revit dan selisih pada lantai atap terjadi karena pekerjaan dinding oleh metode konvensional proyek memiliki durasi 0 hari yang juga disebabkan karena tidak ikut diperhitungkan atau human error. Selisih waktu yaitu 15 hari lebih besar pada metode BIM juga bertentangan dengan peneliti terdahulu Akhmad A. K. et al., (2019) yang menyimpulkan hasil biaya untuk BIM mempercepat waktu sebesar 46,15 dibandingkan menggunakan metode konvensional.

Perbedaan hasil simpulan terhadap peneliti terdahulu dikarenakan studi kasus yang diambil berbeda dan pada perhitungan konvensional dengan persentase RAB perbedaan tertinggi terdapat pada volume balok dan pelat yang terjadi karena human error terhadap perhitungan oleh pihak proyek pada lantai 5 dan presentase Penjadwalan dengan perbedaan tertinggi juga dikarenakan human error terhadap perhitungan oleh pihak proyek pada lantai 1, lantai 5 dan pekerjaan atap.

\section{Kesimpulan dan Saran}

\subsection{Kesimpulan}

Perbandingan biaya antara pemodelan Autodesk Revit dan metode konvensional proyek memiliki selisih Rp 242.638.340,10 yaitu 4,71\% lebih besar pada metode BIM. Selisih biaya diakibatkan karena volume yang berbeda dengan persentase perbedaan tertinggi terdapat pada volume balok dan pelat yang terjadi karena human error pada lantai 5. Durasi waktu pekerjaan yang didapat dari pemodelan Autodesk Revit memiliki jumlah 255 hari dan metode konvensional proyek memiliki jumlah 240 hari sehingga memiliki selisih waktu 15 hari yang diakibatkan perbedaan volume yang telah diperhitungkan.

\subsection{Saran}

Peneliti selanjutnya diharapkan dapat pengembangan lingkup pemodelan dengan pekerjaan MEP dan dapat menggunakan program bantu BIM yang berbeda. Pengembangan lingkup lain seperti perhitungan tenaga kerja optimal agar tercapainya pekerjaan proyek dengan cepat juga dapat digunakan dalam penelitian 
selanjutnya. Peneliti selanjutnya juga diharapkan dapat menggunakan studi kasus dengan tingkat presentase human error yang sedikit, sehingga perbandingan dapat dilakukan lebih detail.

\section{Daftar Kepustakaan}

Berlian, C. A. et al, 2016. Perbandingan Efisiensi Waktu, Biaya, dan Sumber Daya Manusia Antara Metode Building Information Modelling (BIM) Dan Konvensional (Studi Kasus: Perencanaan Gedung 20 Lantai). Karya Teknik Sipil, 5(2), pp. 220-229. Available at: https://ejournal3.undip.ac.id/index.php/jkts/article/view/12641.

Eastman, C. et al, 2008. BIM Handbook: A Guide to Building Information Modeling for Owners, Managers, Designers, Engineers and Contractors, 2nd Edition. pp. 20-21; 65-84; 93-135.

Hatmoko, J. U. D. et al, 2019. Investigating Building Information Modelling (BIM) Adoption in Indonesia Construction Industry. MATEC Web of Conferences, 258, p. 02006. doi: 10.1051/matecconf/201925802006.

Kamil, A. A. and Raflis, 2019. Perbandingan Pengendalian Biaya Mutu dan Waktu Menggunakan Metode Konvensional dan Metode BIM. (April).

Muhtadi, A, 2009. Manajemen proyek berbasis efisiensi waktu pelaksanaan pembangunan gedung polres kabupaten probolinggo. Neutron, 9(2).

Putri, F. F, 2019. Evaluasi Anggaran Biaya Struktur dan Arsitektur Menggunakan Metode Building Information Modeling (BIM) (Studi Kasus: Gedung Integrated Laboratory For Science Policy And Communication IsDB Universitas Jember). pp. 1-43.

Rizaldi, R. I., Farni, I. and Mulyani, R, 2017. Kajian Potensi Bangunan Building Information Modeling (BIM) Dalam Merencanakan Gedung di Indonesia. Abstract of Undergraduate Research, Faculty of Civil and Planning Engineering, Bung Hatta University, 2(2).

Smith. D, 2007. An Introduction To Building Information Modeling (Bim), Journal Of Building Information Modeling, Fall 2007. Jbim, Spring(National Institute of Building Sciences: An Authoritative Source of Innovative Solutions for the Built Environment), p. 44.

Sridadi, 2009. Pemodelan dan Simulasi Sistem.

Trihendra, C, 2008. Microsoft Project 2007. Langkah Cerdas Merencanakan, Menjadwalkan, dan Mengontrol Proyek. 